\title{
Middle Neolithic Absolute Dating In North Croatia - New Research
}

\author{
Katarina Botić, Institute of Archaeology, Zagreb
}

Nove raziskave so v zadnjih petnajstih letih razkrile nekaj novih ključnih informacij o srednjem neolitiku severne Hrvaške. Prvič je bilo južno od reke Drave izkopano najdišče kulture linearno trakaste keramike Donji Miholjac - Vrančari, kar je vodilo do revizije najdb iz starejših izkopavanj na lokacijah Virovitica - Brekinja in Kaniška Iva - Osušak. Spoznali smo nov kronološki položaj in možen nastanek tipa Ražište, medtem ko so vprašanja o poreklu in razvoju kultur Korenovo in Sopot še vedno v veliki meri neodgovorjena. Kronološko modeliranje srednje neolitske sekvence je mogoče le delno zaradi majhnega števila razpoložljivih radiokarbonskih datumov.

Ključne besede: severna Hrvaška, srednji neolitik, pozno starčevo, LTK, Ražište

Over the last I5 years, new research brought to light several new key pieces of information regarding the middle Neolithic in north Croatia. For the first time the LBK site Donji Miholjac - Vrancari was excavated south of Drava river which lead to the revision of finds from older excavations at Virovitica - Brekinja and Kaniška Iva - Osušak sites. New chronological position and possible origin of Ražište type was recognized while questions regarding origin and development of Korenovo and Sopot culture still remain largely unanswered. Chronological modelling of the middle Neolithic sequence is only partially possible due to the low number of available radiocarbon dates.

Key words: north Croatia, middle Neolithic, late Starčevo, LBK, Ražište

$\mathrm{N}$

orth Croatia, mostly territory between three mayor rivers, Sava, Drava and Danube, was populated by Starčevo culture during the early and Sopot culture with its local variants during the late phase of the Neolithic with late Vinča culture present in its final stages in the most eastern part of the territory (Marković 1994, 27). Term middle Neolithic was seldom used because there were no evidences, or no evidences were published, of Transdanubian LBK culture besides its variant recognized as Korenovo culture (Dimitrijević 196I; Dimitrijević 1979; Težak-Gregl 1993). Korenovo culture occupied north-western part of Croatia in two stages, A and B, first present at Kaniška Iva - Osušak site and the second on most of the known sites including Malo Korenovo. This term was used to describe a time of Vinča A-B phases, the end of Korenovo culture and the beginning of Sopot culture in eastern Slavonia (Marković 1994, 27).

New archaeological research conducted on large infrastructure, such as road or gas pipeline construction, and very rarely small scale systematic excavations, yielded new and very interesting results. Several sites are of specific interest and the results obtained from the research conducted there will be discussed further. 


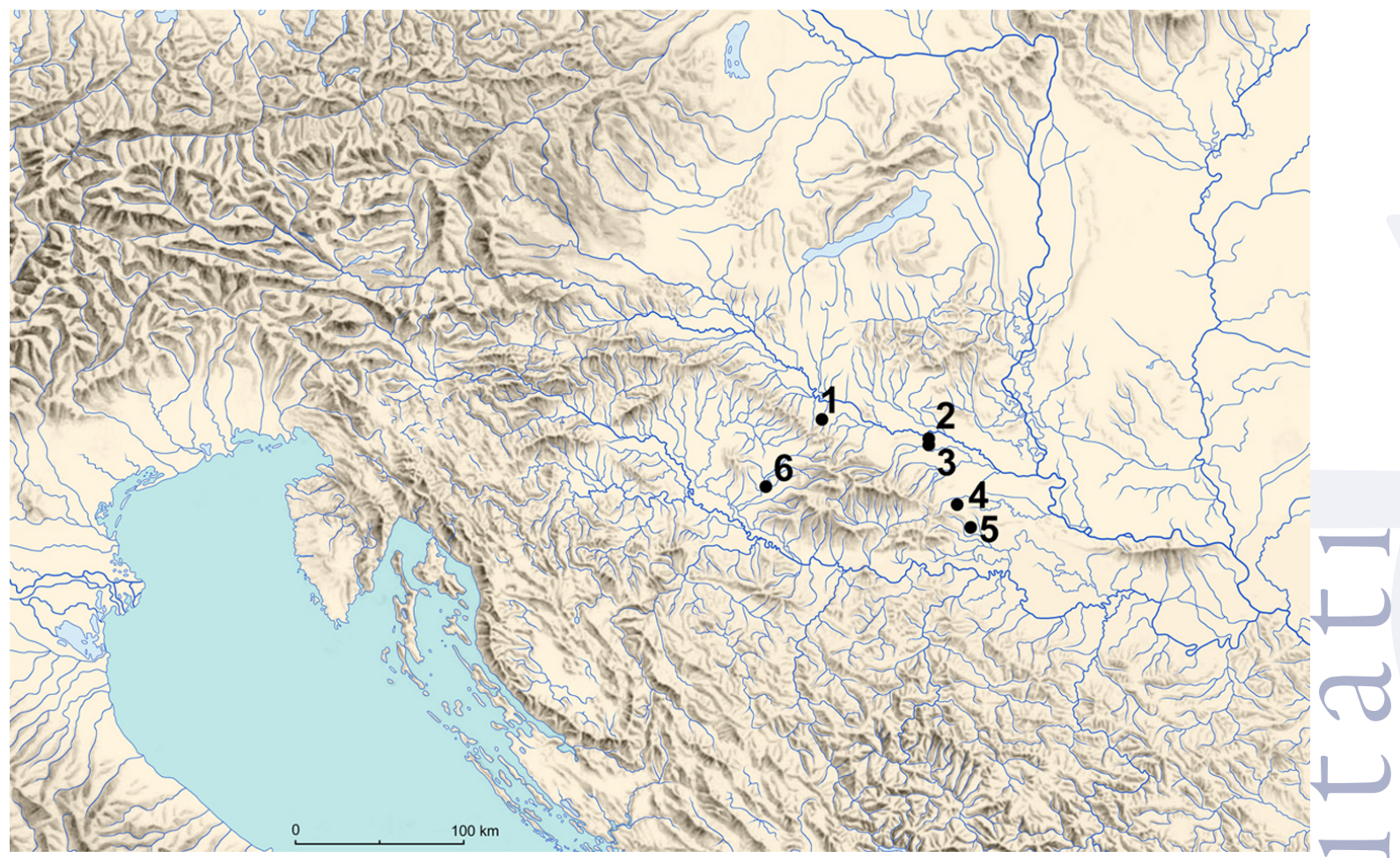

Figure I. I. Virovitica - Brekinja; 2. Donji Miholjac - Vrancari; 3. Golinci - Selište; 4. Podgorač - Ražište; 5. Novi Pẹrkovci - Krčavina; 6. Kaniška Iva - Osušak (made by K. Botić).

\section{Virovitica - Brekinja}

(FigureI, I; Figure 2, I)

The site was excavated in 2005 on a bypass road southwest of Virovitica in Virovitica-Podravina County. Of $9000 \mathrm{~m}^{2}$ excavated, the Neolithic settlement occupied $5400 \mathrm{~m}^{2}$ (Sekelj-Ivančan and Balen 2006a, 67; Sekelj-Ivančan and Balen 2006b, 76; Sekelj-Ivančan and Balen 2007, 21; Đukić 2014, I08). The features and finds were published as Starčevo but after the recent revision it was concluded that large number of features belongs to houses similar in construction to long houses of LBK type (Botić 2017, 69-7I). Two radiocarbon dates were published, both AMS (Sekelj-Ivančan and Balen 2007, 24): Beta 212603, charcoal, $6470 \pm 70 \mathrm{BP}, 5488-5364 \mathrm{cal}$ BC (68.2\%), 5557-5312 cal BC (95.4\%) and Beta 21260I, charcoal, $6350 \pm 80 \mathrm{BP}, 5465-5228 \mathrm{cal} \mathrm{BC}$ (68.2\%), 5482-5079 cal BC (95.4\%).

\section{Donji Miholjac - Vrancari}

(Figure 1, 2; Figure 3)

The site was excavated in 2015 on a bypass road southwest of Donji Mihojac in Osijek-Baranja County. The excavated area was $5400 \mathrm{~m}^{2}$. The features and finds belong to Transdanubian LBK culture with some possible Starčevo finds (Dizdar and Tonc 2016). Pottery has all the characteristics of this culture: sand and gravel tempering of coarse wares, chaff tempering, attempt of polished surface and low quality of firing of fine wares, finger impression motif under the rim of the vessels, deeply incised spiral motif etc. Four dates were obtained for this site, all AMS (Botić 2017, 23I): DeA-rio80, charcoal, $6420 \pm 32 \mathrm{BP}, 5467-5369$ cal BC (68.2\%), 5472-5331 cal BC (95.4\%); DeA-11168, non-articulated animal bone, $6416 \pm 40 \mathrm{BP}, 5468-5364$ cal BC (68.2\%), 5472-5325 cal BC (95.4\%); DeAIII66, non-articulated animal bone, $6379 \pm 36$ 


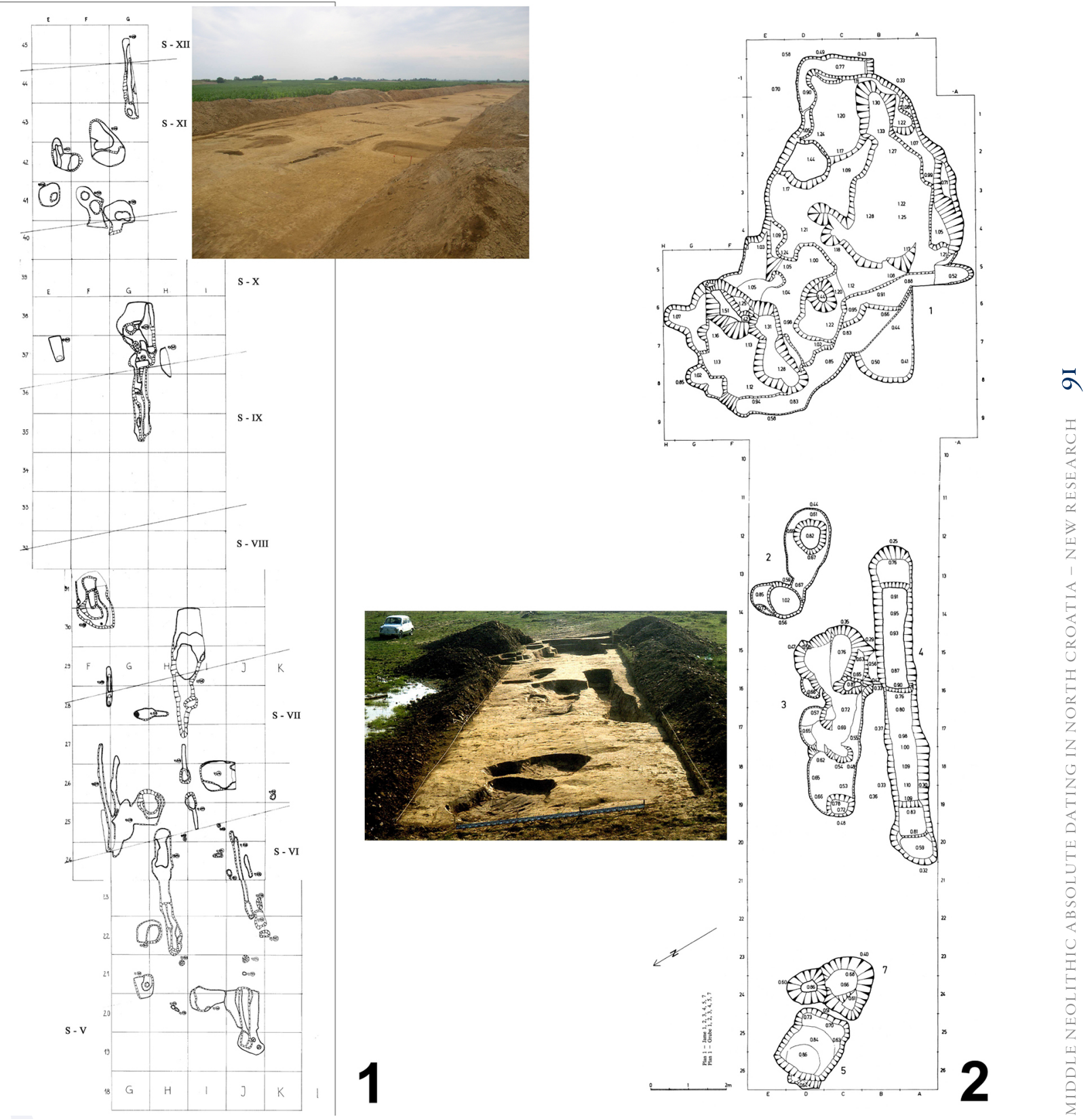

Figure 2. I. Virovitica - Brekinja (Sekelj-Ivančan and Balen 2006a, 68; Sekelj-Ivančan and Balen 2006b, 77); 2. Kaniška Iva - Osušak (Težak-Gregl 199ı, Plan I; Jakovljević 2006, 29)

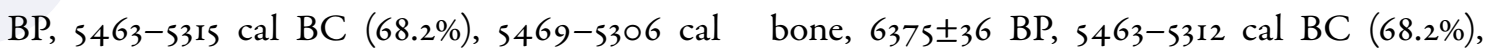
BC (95.4\%); DeA-iri67, non-articulated animal $5469-5304$ cal BC (95.4\%). 

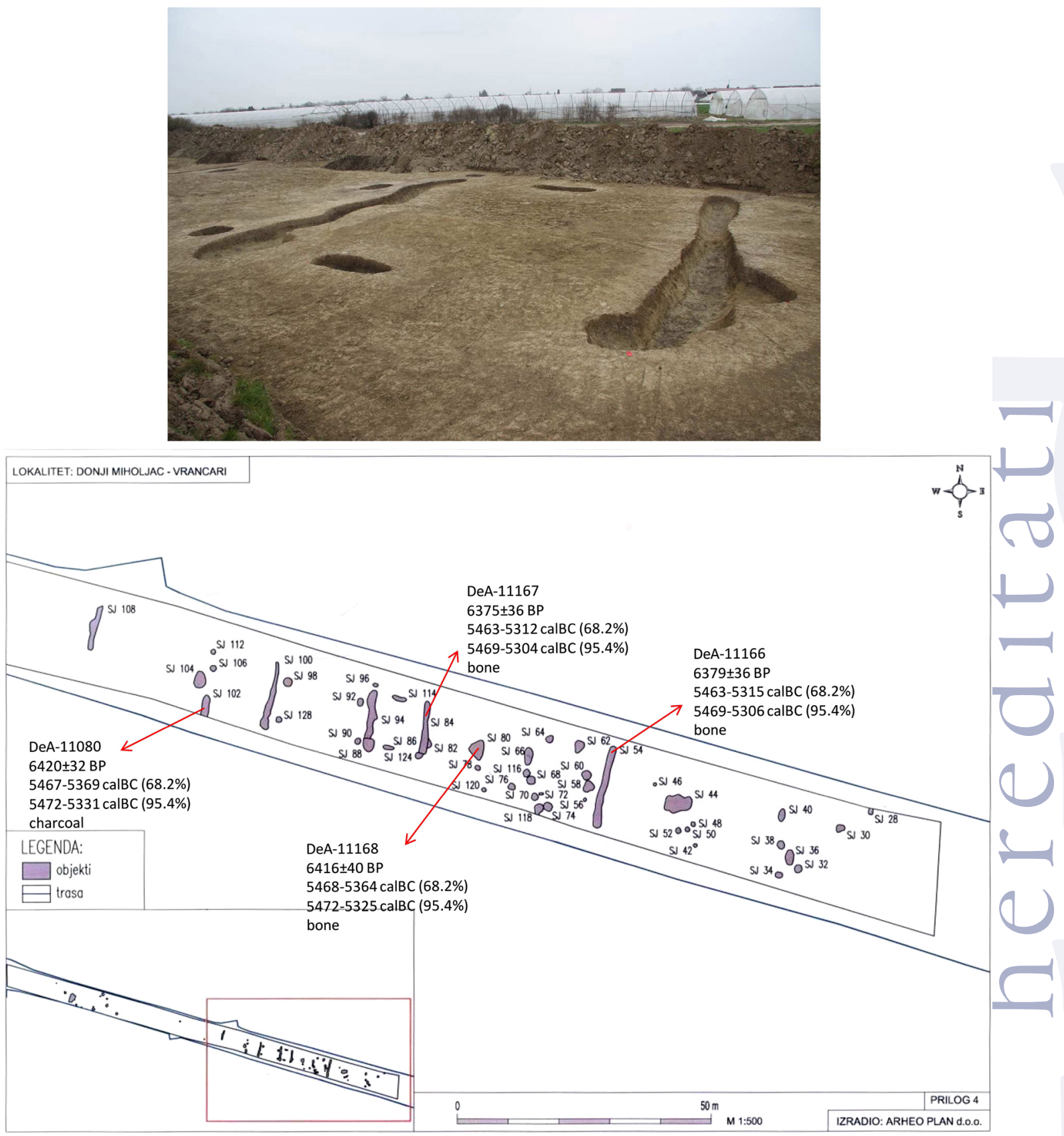

Figure 3. Donji Miholjac - Vrancari (Dizdar and Tonc 2016,38, Fig. 3; plan made by Arheo plan Ltd. and K. Botić)

Podgorač - Ražište (Figure I, 4; Figure 4) The site, situated east of Našice in Osijek-Baranja County, was excavated in 1975 and again in 2013 and 2015 as a part of small scale systemat- ic research. In 1975 an area of $75 \mathrm{~m}^{2}$ was explored (Marković 1985 ) with additional $150 \mathrm{~m}^{2}$ in 2013 and 2015 (Marković and Botić 2014; Marković and Botić 2016). Three large pits were excavated, a few smaller ones and a part of larger ob- 

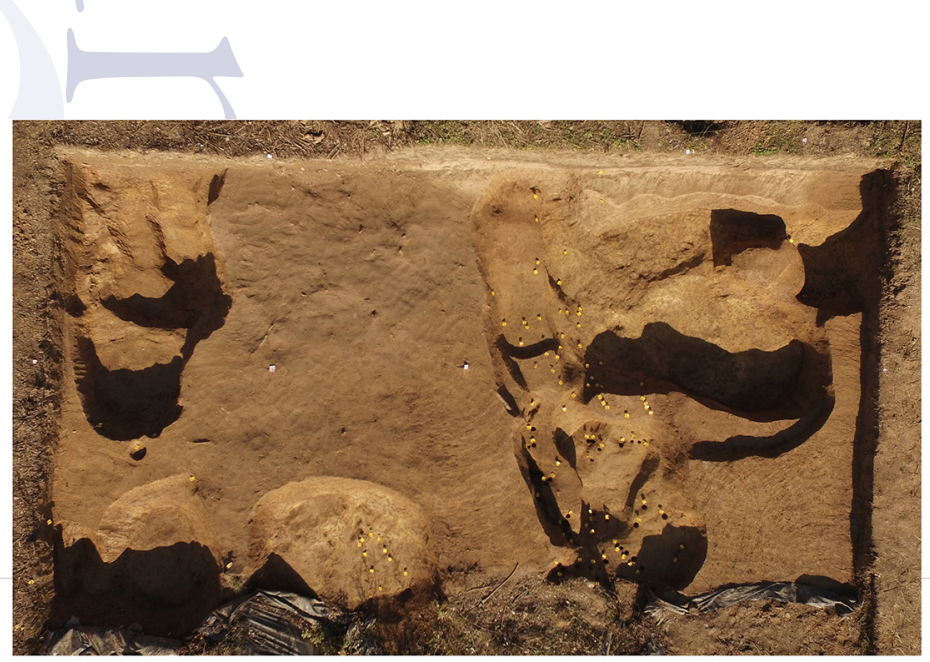

ject, possibly a long house (Botić 2017, 59-6I). Z. Marković realized that pottery finds from this site and several sites in the region around Našice are different form classical Sopot finds and in 1985 he determined this style as Ražište type of Sopot culture. Excavations in 2013 and 2015 confirmed the hypothesis of different style but went further and established an older pottery phase which consists of globular and pedestaled vessels but without typical Ražište elements such as zoomorphic appliques or incised semi-circular motifs. Three dates were obtained for this site, all AMS (Marković and Botić 2016, 66; Botić 2017, 230): DeA-8339, charcoal, 6413 \pm 30 BP, 5467$5364 \mathrm{cal} \mathrm{BC} \mathrm{(68.2 \% ),} 5470-5327 \mathrm{cal} \mathrm{BC} \mathrm{(95.4 \% );}$ DeA-8338 charcoal, 6109 \pm 29 BP, $5196-4987 \mathrm{cal}$ BC (68.2\%), 5207-4943 cal BC (95.4\%); DeA- 
5159, charcoal, 6004 27 BP, 4934-4848 cal BC (68.2\%), 4982-4806 cal BC (95.4\%).

\section{Golinci - Selište (Figure I, 3)}

The site was excavated in 2009 on a gas pipeline southeast of Donji Miholjac in Osijek-Baranja County. The excavated area was $575 \mathrm{~m}^{2}$. Smaller features were excavated, which yielded finds of Ražište type of pottery among other. The pottery from this site has both characteristics of younger phase of Ražište style and of LBK elements not entirely present at Ražište site so far. It is not clear what the excavated features represent because of a very narrow area excavated. One AMS date has been published from this site (Čataj and Janeš 2013, 170; Botić 2017, 223): LTL $5772 \mathrm{~A}$, charcoal, 6160 $\pm 45 \mathrm{BP}, 5207-5054 \mathrm{cal}$ BC (68.2\%), 5226-4980 cal BC (95.4\%).

\section{Novi Perkovci - Krčavina (Figure I, 5)}

The site was excavated in 2005 and 2006 on a highway southwest of Đakovo in Osijek-Baranja County. The excavated area was $18000 \mathrm{~m}^{2}$. Features from various Neolithic phases were excavated although it is not clear if some of them represent long houses from the Neolithic period (there were traces of middle and late Bronze Age settlements and possibly cemetery at the site). Pottery shows Ražište type elements but with more Sopot and Vinča influences. Two conventional radiocarbon dates are available from this site (Marković and Botić 2008, 16-17; Botić

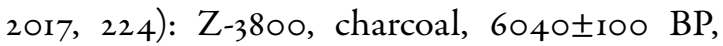
$5191-4798$ cal BC (68.2\%), 5216-4720 cal BC (95.4\%); Z-3799, charcoal, $5862 \pm 138 \mathrm{BP}, 4897-$ 4549 cal BC (68.2\%), 5198-4374 cal BC (95.4\%).

To these sites new observations should be added about Kaniška Iva - Osušak site (Figure I, 6; Figure 2, 2), excavated in 1978 (Težak-Gregl 199I). It also become clear in the recent revision that the feature 4 (Težak-Gregl I99I, Plan I), a long pit, can represent part of a long house (Botić 2017, 73-74). This observation is even more plausible if we bear in mind that it belongs to Korenovo culture, a local variant of LBK. However, no radiocarbon dates are available for this site or the
Korenovo culture in general besides the partially published date from site Kukunjevac - Brod excavated in 2012 near Lipik in Požega-Slavonia County: Beta-340932, 4940-4790 cal BC (95\%) (Ivanković 2013, 173; Ivanković 2014, 58).

\section{Discussion}

Virovitica - Brekinja site, situated in a flat Drava region, shows similar characteristics to Szentgyörgyvölgy-Pityerdomb site, situated west of the Balaton Lake. On this site long houses were found and the pottery shows both late Starčevo and earliest LBK characteristics. Although most of the finds from Virovitica - Brekinja site were not published, there is a fragment of a bell shaped pedestal that is worth mentioning. This pedestal was incorporated in the conical pedestaled vessel reconstruction (Sekelj-Ivančan and Balen 2007, 25; Đukić 2014, I09, cat. no. 304) and described as of Starčevo provenience but it bears great similarity with a bell shaped pedestal from Szentgyörgyvölgy-Pityerdomb site (Bánffy 2004, 106-107, Fig. 40: 29, 232). It is very possible that the same coexistence of two pottery stiles occurred at Virovitica - Brekinja site. Szentgyörgyvölgy-Pityerdomb site is dated between 5480 and 5360 cal BC (Bánffy 2004, 299-309; Oross and Bánffy 2009, 179) which, again, is similar to dates obtained for Virovitica - Brekinja site.

Further east, very close to one of the Drava river crossings, is Donji Miholjac - Vrancari site. It is unique in its inner structure of long houses and pottery of clearly Transdanubian LBK features. This is the first such site recognized south of Drava river and although there is a very small percentage of finds of possible late Starčevo provenience, most of it is LBK. Dates from this site correspond to the dates from Virovitica - Brekinja site.

About $30 \mathrm{~km}$ south-east, near Našice, Podgorač - Ražište site is situated. Pottery style of this site was recognized somewhat different from classical Sopot pottery and named Ražište type in 1985 but new excavations showed that what was firstly recognized was actual- 


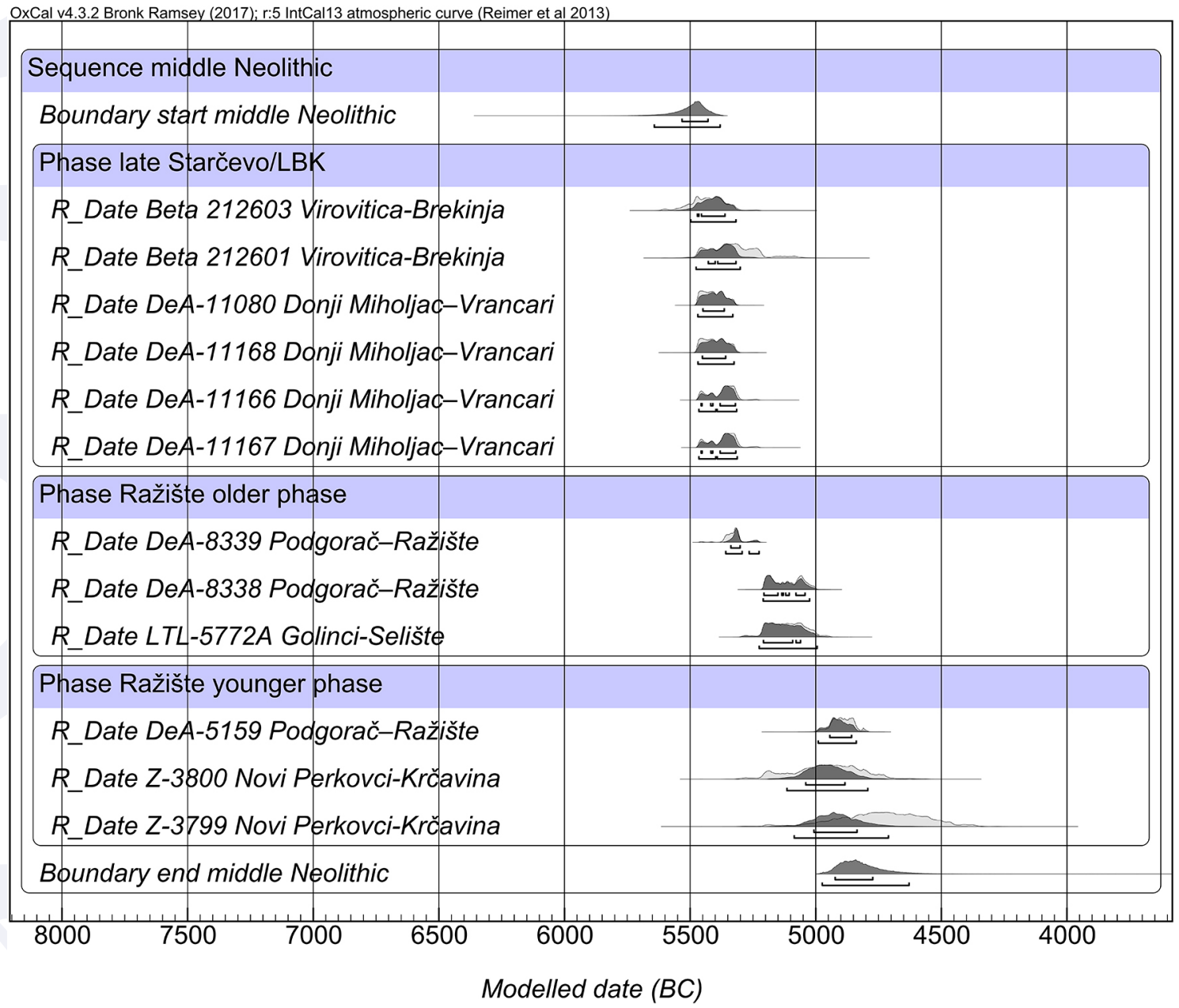

Figure 5. Middle Neolithic sequence for northern Croatia (OxCal 4.3.2)

ly the younger phase. Two other sites yielded same or similar pottery style: Golinci - Selište site, a few kilometres south-east of Donji Miholjac and Novi Perkovci - Krčavina site about 25 $\mathrm{km}$ to the south-east (near Đakovo). While pottery from Golinci - Selište site exhibit certain features, such as zoomorphic applications, similar to the younger Ražište phase, other features, such as low incised linear motif curving downwards (Čataj and Janeš 2013, 175, Fig. 6), are more similar to LBK. Pottery from Novi Perkovci Krčavina site (Marković and Botić 2008) has more in common with classical Sopot and latter Vinča cultures which is not surprising con- sidering their geographical and temporal closeness. Dates for older phase of Ražište type are two older dates from Ražište site itself and the date from Golinci - Selište while younger phase is represented by the youngest date from Ražište site and two dates from Novi Perkovci - Krčavina site.

All these sites with their internal structure, movable finds and radiocarbon dates compose a middle Neolithic sequence (Figure 5). Dates for the late Starčevo/LBK group around $5400 \mathrm{BC}$ and are closely followed by the oldest date from Ražište site. Sample for this date was submitted as charcoal but it was latter realised that the ma- 
terial in question is non-charred organic matter. It is possible that the sample consisted of thin branches or some weed or seeds but during the excavation the soil condition didn't permit this identification.

The second date from Ražište site corresponds to the date from Golinci - Selište site but unfortunately these two dates fall into the small plateau in the calibration curve. The youngest date from Ražište site and two dates from Novi Perkovci - Krčavina site also correspond to each other. These last two conventional dates show obvious problems and can't be considered as the end dates for the middle Neolithic sequence.

Contemporaneity of some sites is further stressed by architecture as it is the continuity of pottery stiles on the others. Even in geographical terms sites situated west and closer to the LBK core area are dated older than the sites situated further east. Of course, this is true for the current state of research and for very small sample of radiocarbon dates but nevertheless it seems indicative. The beginning of the middle Neolithic sequence is a time of LBK expansion from its core area (Jákucs et al. 2016, 323-324; Dubouloz et al. 2017) and sites such as Szederkény-Kukorica-dűlő (Jákucs et al. 2016) and Versend-Gilencsa (Jákucs and Voicsek 2017) south-east of Pecs in Hungarian Baranya appear at that time. The former was dated between 5340-5315 BC and 5200-5180 BC, western part of the settlement containing Ražište pottery while eastern part contained Vinča A (both mixed with some LBK finds) (Jákucs et al. 2016, 278), while latter was dated between 5235-5215 BC and 5210-5195 BC, western part containing Korenovo and Ražište finds while eastern part contained late Starčevo, early LBK and early Vinča finds (Jákucs and Voicsek 2017, 176). Houses on both sites were long houses of LBK type.

Two questions remain open: the position of Korenovo culture and the appearance of classical Sopot culture in the absolute chronological terms. For Korenovo culture only one partial date is known from northern Croatian territory which was published together with a few red painted fragments correlating well with pottery finds known from sites north of Drava river and with dates from Versend-Gilencsa site, representing the last B-2 stage parallel to Vinča $B$ and transition to Vinča $C$ phase. However, the beginning of this culture still remains unclear, both related to dating and to its possible origin.

The beginning of Sopot culture was considered parallel to Vinča B by S. Dimitrijević (1979, 268) and Z. Marković (1994, 63) in its core area, i.e. the eastern Slavonia region. That would suggest the beginning of Sopot culture around or after $5200 \mathrm{BC}$, duration of this initial phase until 5000 BC (Vinča B - Borić 2009, 234) and the possible phase II between $5000 / 4950$ and 4850 BC (Vinča C - Borić 2009, 234). However, most of the Sopot dates available correspond to the time after the $5000 \mathrm{BC}$ and the oldest phase according to Obelić et al. (2004) can't be considered (Burić 2015) because the dates for Dubovo - Košno site situated about $20 \mathrm{~km}$ south of tell Sopot are conventional dates, none originating from a short-lived sample (Burić 20I5, I52) and because that would mean the initial I-A phase would be older than Vinča A phase (Burić 2015, 152; Botić 2017, 75, note 85). Considering two published Sopot dates from SormásMántai-dűlő site in Zala Conty (western Transdanubia), there must have been an earlier Sopot phase: VERA-3102, animal bone, 6115 $\pm 35 \mathrm{BP}$, $5203-4984 \mathrm{cal} \mathrm{BC}(68.2 \%), 5208-4948 \mathrm{cal} \mathrm{BC}$ (95.4\%); VERA-3103, animal bone, 6045 \pm 50 BP, 5006-4849 cal BC (68.2\%), 5198-4798 cal BC (95.4\%) (Barna and Pásztor 2011, 189, Tab. I). Again, this phase could have started around $5200 \mathrm{BC}$ or slightly before in a core area which would mean that Sopot culture spread quickly to the west. There is, of course, possibility that it wasn't Sopot culture but rather Ražište type that spread westwards around $5200 \mathrm{BC}$. In that case, appearance of Sopot culture in its core area around $5200 \mathrm{BC}$ is quite possible. Burić (2015, I5I) considers eastern Slavonia, i.e. region between Bapska in the east, Vinkovci area in the west and eastern Sava region in Bosnia in the south as a core area of Sopot culture while north- 
ern point is not very clear but should be located towards southern Hungary. Several other radiocarbon dates can't be used as the oldest dates for Sopot culture: sample Z-2826 (6340 \pm 100 BP) from Sopot taken from the wall of a house SU II, belonging to the youngest III/IV phase according to the excavator (Krznarić Škrivanko 20II, 2II, 220, Tab. I; Botić 2017, 225, note 195); sample Z-3868 (6295 \pm 135 BP) from Sopot taken from a house floor SU i8za, belonging to the II phase according to the excavator (Krznarić Škrivanko 201I, 21I, 220, Tab. I; Botić 2017,

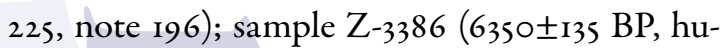
man bone) from a grave at Kneževi vinogradi - Osnovna škola site because there was no pottery close to the skeleton and at the bottom of the pit containing the burial, remains of Starčevo and Sopot pottery were found in a mixed context (Šimić 2004, 77; Botić 2017, 223, note 193). On the other hand, Sraka's (2012) chronological model of tell Sopot house phases and their dating shows problems regarding dating the phase III of Sopot culture after $4300 \mathrm{BC}$, disregarding in the process the possibility of existence of the phase IV (Marković 1994, 63; Balen et al. 2009, 35).

\section{Concluding Remarks}

Over the last is years new research brought to light very interesting new results which complemented older partial information. For the first time a phase in southern expansion of Transdanubian LBK was documented south of Drava river forcing us to reconsider older finds. Another point of entry should be considered somewhere westwards along the Drava river bearing in mind the position of Szentgyörgyvölgy-Pityerdomb, one of the earliest LBK sites in western Transdanubia. New information about Ražište type changes its chronological position from phase I-A/I-B of Sopot culture (Marković 1985, 495I; Marković 20I2, 58) or beginning of Vinča B phase, to the very beginning of Vinča A phase as recognized at southern Hungarian sites Szederkény-Kukorica-dűlő (Jákucs et al. 2016) and Versend-Gilencsa (Jákucs and Voicsek 2017).
According to typological differences and radiocarbon dates, two phases of Ražište type can be distinguished. It would seem that the older Ražište phase would predate the beginning of Sopot culture.

Chronological modelling of available radiocarbon dates shows continuity of life from late Starčevo phases in this area during the middle Neolithic but it is not very clear regarding the end date due to the lack of AMS dates and lack of further research in wither territory.

One of the interesting points surging from the new research is the fact that Ražište type, almost as much as Korenovo culture, has its origins in the LBK world. The question what was the nature of its relationship with the late Starčevo, LBK and Vinča cultures in its early phase still remain open as well as its relationship with Sopot culture latter on. New research, however, failed to answer the question of the origin and development of Korenovo culture although it provided us with more information about its end phase. The same goes for the emergence and development of Sopot culture although this is more due to the lack of publication rather than the lack of information.

\section{Povzetek}

Nove raziskave so v zadnjih is letih razkrile zelo zanimive rezultate, ki so dopolnjevali starejše delne informacije o srednjem neolitiku severne Hrvaške. Prvič je bila na južni strani reke Drave na lokaciji Donji Miholjac - Vrančari dokumentirana faza širjenja transdanubijske kulture linearno trakaste keramike (LTK) na jug. Prepoznane so bile tudi nekatere podobnosti med enim od najzgodnejših najdišč LTK v zahodnem Podonavju Szentgyörgyvölgy-Pityerdomb in najdiščem Virovitica - Brekinja. Nove informacije o tipu Ražište spreminjajo njegov kronološki položaj iz faze IA / IB sopotske kulture (Marković 1985, 49-51; Marković 2012, 58) oziroma začetka faze Vinča B, na sam začetek faze Vinča A, kot prepoznana na južno madžarskih najdiščih Szederkény-Kukorica-dủlő (Jákucs et al. 2016) in Versend-Gilencsa (Jákucs and Voicsek 2017). Dve fazi tipa Ražište lahko glede na tipološke razlike in radiokarbonske datume ločimo na treh najdiščih: Podgorač - Ražište, Golinci - Selište in Novi Perkovci - Kr- 
čavina. Zdi se, da je starejša faza tipa Ražište zgodnejša od začetka sopotske kulture. Kronološko modeliranje razpoložljivih radiokarbonskih datumov kaže na kontinuiteto življenja od poznih faz starčevačke kulture do začetka poznega neolitika v osrednjem in zahodnem delu severne Hrvaške. Ena izmed zanimivosti, ki izhaja iz nove raziskave, je dejstvo, da ima tip Ražište, skoraj toliko kot korenovska kultura, svoj izvor v svetu LTK. Vprašanje, kakšna je bila narava njegovega odnosa s pozno kulturo Starčevo, LTK in vinčansko kulturo v njegovi zgodnji fazi, je še vedno odprto, prav tako pa tudi njegov kasnejši odnos s sopotsko kulturo. Nastanek in razvoj korenovske kulture ostaja nejasen, čeprav nam je nova raziskava priskrbela nekaj več informacij o njeni končni fazi. Enako velja za nastanek in razvoj kulture sopotske kulture, čeprav je to bolj posledica pomanjkanja publikacij kot informacij.

\section{Summary}

Over the last is years, new research brought to light very interesting new results which complemented older partial information about the middle Neolithic in the north Croatia. For the first time a phase in southern expansion of Transdanubian LBK was documented south of Drava river on Donji Miholjac - Vrancari site. Some similarities between Szentgyörgyvölgy-Pityerdomb, one of the earliest LBK sites in western Transdanubia and Virovitica - Brekinja site were recognized. New information about Ražište type changes its chronological position from phase I-A/I-B of Sopot culture (Marković 1985, 49-51; Marković 20I2, 58) or beginning of Vinča B phase, to the very beginning of Vinča A phase as recognized on southern Hungarian sites Szederkény-Kukorica-dúlő (Jákucs et al. 2016) and Versend-Gilencsa (Jákucs and Voicsek 2017). According to typological differences and radiocarbon dates, two phases of Ražište type can be distinguished on three sites: Podgorač - Ražište, Golinci - Selište and Novi Perkovci - Krčavina. It would seem that the older Ražište phase would predate the beginning of Sopot culture. Chronological modelling of available radiocarbon dates shows continuity of life from late Starčevo phases to the beginning of the late Neolithic in the central and western parts of north Croatia. One of the interesting points surging from the new research is the fact that Ražište type, almost as much as Korenovo culture, has its origins in the LBK world. The question what was the nature of its relationship with the late Starčevo, LBK and Vinča cultures in its early phase still remain open as well as its relationship with Sopot culture latter on. The origin and development of Korenovo culture remains unclear although the new research provided us with more information about its end phase. The same goes for the emergence and development of Sopot culture although this is more due to the lack of publication rather than the lack of information.

\section{References}

Balen, J., T. Bilić, M. Bunčić, I. Drnić, and A. Solter. 2009. "Rezultati zaštitnih istraživanja na lokalitetu Ivandvor Šuma Gaj." Vjesnik Arheološkog muzeja u Zagrebu XLII: 23-72.

Bánffy, E. 2004. The 6th millennium BC boundary in western Transdanubia and its role in the central European Neolithic transition (Szentgyörgyvölgy - Pityerdomb settlement). Varia Archaeologica $\checkmark$ Hungarica XV. Budapest: Archaeological Institute of HAS.

Barna, J. P., and E. Pásztor. 20II. “Different ways of using space: traces of domestic and ritual activities at a Late Neolithic settlement at Sormás-Török-földek.” Documenta Praehistorica XXXVIII: I85206. https://doi.org/10.4312/dp.38 Borić, D. 2009. „Absolute Dating of

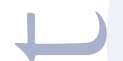
$\checkmark$ 0 $\sqrt{ }$ rar Metallurgical Innovations in the Vinča Culture of the Balkans." In Metals and Societies. Studies in honour of Barbara $S$. Ottaway, edited by T. K. Kienlin and B. W. Roberts, Universitätsforschungen zur prähistorischen Archäologie, Bd. I69, I9I-245. Bonn: Verlag Dr. Rudolf Habelt $\mathrm{GMBH}$.

Botić, K. 2017. "Neolitička naselja na prostoru sjeverne Hrvatske.” PhD diss., University of Zagreb.

Burić, M. 2015. "Problems of the Late Neolithic Absolute Chronology in Eastern Croatia." Archäologie in Eurasien 31: 143-56.

Čataj, L., and A. Janeš. 2013. "Golinci-Selište. Prehistoric and Medieval settlement." In New archaeological insight into lower 
Podravina, Rescue Archaeological Research of the Slobodnica - Donji Miholjac Natural Gas Trunk Pipeline, edited by J. Višnjić, 167-225. Zagreb.

Dimitrijević, S. 196I. "Problem neolita i eneolita u sjeverozapadnoj Jugoslaviji.” Opuscula archaeologica 5: 5-78.

Dimitrijević, S. 1979. “Sjeverna zona.” In Praistorija jugoslavenskih zemalja, II, Neolitsko doba, edited by A. Benac, 229-359. Sarajevo: Akademija nauka i umetnosti Bosne i Hercegovine - Centar za Balkanska ispitivanja.

Dizdar, M., and A. Tonc. 2016. "Rescue excavations of the AN 2 Donji Miholjac - Vrancari site." Annales Instituti Archaeologici XII: $36-39$.

Dubouloz, J., J.-P. Bocquet-Appel, and R. Moussa. 2017. "Modélisation, simulation et scenarios d'expérimentation, La colonisation LBK de l'Europe tempérée (5550-4950 av.n.e.)." In European Archaeology, Identities \& Migrations / Archéologie européenne, identités \& migrations, Hommages à Jean-Paule Demoule, edited by L. Manolakakis, N. Schlanger and A. Coudart, 315-37. Leiden: Sidestone Press.

Đukić, A. 2014. "Virovitica - Brekinja." In Darovi zemlje - neolitik izmedu Save, Drave i Dunava, exhibition catalogue II, edited by J. Balen, T. Hršak and R. Šošić Klindžić, ıo8-9. Zagreb - Osijek: Arheološki muzej, Sveučilište u Zagrebu, Filozofski fakultet - Muzej Slavonije.

Ivanković, A. 2013. "Lokalitet: Kukunjevac - Brod (AN 25)." Hrvatski arheološki godišnjak 9/2012: 17I-74.

Ivanković, A. 20I4. "Kukunjevac - Brod." In Darovi zemlje - neolitik izmedu Save, Drave i Dunava, exhibition catalogue II, edited by J. Balen, T. Hršak and R. Šošić Klindžić, 57-58. Zagreb - Osijek: Arheološki muzej, Sveučilište u Zagrebu, Filozofski fakultet - Muzej Slavonije. Jakovljević, G. 2006. "Bjelovarsko-bilogorska županija.” In Stotinu hrvatskih arheoloških nalazišta, edited by A. Durman, 27-29. Zagreb: Leksokografski zavod Miroslav Krleža.

Jákucs, J., E. Bánffy, K. Oross, V. Voicsek, Ch. Bronk Ramsey, E. Dunbar, B. Kromer, A. Bayliss, D. Hofmann, P. Marshall, and A. Whittle. 2016. "Between the Vinča and Linearbandkeramik Worlds: The Diversity of Practices and Identities in the 54th-53rd Centuries cal BC in Southwest Hungary and Beyond." Journal of World Prehistory 29: 267-336. https://doi.org/10.1007/ siog63-016-9096-x

Jákucs, J., and V. Voicsek. 2017. “A Kr. e. 6. évezred második felének új kutatási eredményei Baranya megyében / Recent results in research of the second half of the 6th millennium BC in Baranya County." A Janus Pannonius Múzeum Évkönyve 54: 133-177.

Krznarić Škrivanko, M. 20II. "Radiokarbonski datumi uzoraka sa Sopota.” In Panonski prapovijesni osviti - Zbornik radova posvećen Korneliji Minichreiter uz 65 . obljetnicu života, edited by M. Dizdar, 209-25. Zagreb: Institut za arheologiju.

Marković, Z. 1985. "Ražište-tip sopotske culture." Arheološki vestnik 36: 39-76.

Marković, Z. 1994. Sjeverna Hrvatska od neolita do brončanog doba: problem kontinuiteta stanovništva i kultura sjeverne Hrvatske od ranog neolita do početka brončanog doba. Koprivnica: Muzej grada Koprivnice.

Marković, Z. 2012. „Novija razmatranja o nekim aspektima sopotske kulture u sjevernoj Hrvatskoj / Neuere Betrachtungen über bestimmte Aspekte der Sopot-Kultur in Nordkroatien“. Prilozi Instituta za arheologiju u Zagrebu 29: 5769.

Marković, Z., and K. Botić. 2008. "O neolitičkoj keramici iz Novih Perkovaca kod Đakova." Prilozi Instituta za arheologiju u Zagrebu 25: 15-32.

Marković, Z., and K. Botić. 20I4. "Podgorač, Ražište - rezultati arheoloških istraživanja 
2013. godine." Annales Instituti

Archaeologici X: 63-68.

Marković, Z., and K. Botić. 2016. "Podgorač,

Ražište - rezultati arheoloških istraživanja 2015. godine." Annales Instituti

Archaeologici XII: 63-70.

Obelić, B., M. Krznarić Škrivanko, B.

Marijan, and I. Krajcar Bronić. 2004.

"Radiocarbon dating of Sopot culture sites (Late Neolithic) in Eastern Croatia."

Radiocarbon 46, no. I: 245-58.

Oross, K., and E. Bánffy. 2009. “Three

successive waves of Neolithisation:

LBK development in Transdanubia."

Documenta Praehistorica XXXVI: 175-89.

Sekelj-Ivančan, T., and J. Balen. $2006 a$.

"Prapovijesno naselje Virovitica -

Brekinja." Annales Instituti Archaeologici

II: $67-72$.

Sekelj-Ivančan, T., and J. Balen. 2006b.

"Lokalitet: Virovitica-Brekinja." Hrvatski

arheološki godišnjak 2/2005: 76-78.

Sekelj-Ivančan, T., and J. Balen. 2007.

"Brekinja." In Zapadna Virovitička

obilaznica - Zaštitna arheološka

istraživanja 2005/2006. godine, edited by D.

Sabolić, 19-26. Virovitica: Gradski muzej.

Sraka, M. 2012. " ${ }^{14} \mathrm{C}$ calendar chronologies and cultural sequences in $5^{\text {th }}$ millennium BC in Slovenia and neighbouring regions."

Documenta Praehistorica XXXIX: 349-

76. https://doi.org/I0.4312/dp.39

Šimić, J. 2004. “Kneževi Vinogradi - Osnovna

škola, zaštitno istraživanje neolitičkog

lokaliteta." Obavijesti Hrvatskog

arheološkog društva XXXVI/2: 74-79.

Težak-Gregl, T. 1991. "Naselje korenovske

kulture u Kaniškoj Ivi.” Opuscula

archaeologica I5: I-23.

Težak-Gregl, T. 1993. Kultura linearnotrakaste

keramike u središnjoj Hrvatskoj.

Dissertationes et Monographiae 2. Zagreb:

Arheološki zavod Filozofskog fakulteta

Sveučilišta u Zagrebu. 